\title{
Passing the Baton at the Journal of Early Modern History
}

\section{Dear Readers,}

This issue, marking the midway point of our journal's twenty-fifth year, also marks a number of other important transitions at JEMH. First, and most bittersweetly, it brings to an end Simon Ditchfield's long and distinguished tenure as JEMH editor. Simon first began his duties as our editor-in-chief in January of 2011, taking over from James Tracy, an original founder of the Journal. But he in fact joined the editorial team even earlier, in 2008, when he signed on for a three-year term as book review editor. In all, Simon has thus logged a total of more than thirteen years of service for the Journal. As editor, between individual submissions and special issues, he has shepherded through some 235 published articles out of a total of close to one thousand manuscript submissions. Over the same period, JEMH's readership (measured by total downloads) and its impact (measured by citations) have grown relentlessly. By these metrics, but just as much by general reputation, it stands today alongside the Renaissance Quarterly as the world's premier journal of early modern studies.

In the meantime, unbeknownst to readers, Simon's steady hand has guided our editorial ship through every manner of treacherous waters: precarious budgets, cantankerous authors, recalcitrant referees, unexpected staffing transitions, and at least one threat of legal action. Without exception, all such challenges were tactfully approached and amicably resolved, with nary a grumpy look or even the suggestion of an uncharitable word from our editor. Indeed, even the end of his tenure was planned with characteristic grace and foresight, Simon first giving notice to us of his intention to step down well over a year ago, to ensure plenty of time to find a suitable successor (on whom more below). In short, it has truly been a privilege to share the masthead with Simon during the past decade. He will be sorely missed, although the end of his tenure as editor will thankfully be mitigated by his continuing contributions to the journal in other capacities. These include a special issue to commemorate JEMH's twenty-fifth anniversary, scheduled to appear at the end of this year and for which Simon will serve as a guest editor, after which he will continue to advise us as a member of our editorial board. 
As we congratulate Simon and welcome him into this new role, it is with equal pleasure that we welcome his successor as JEMH editor, Prof. Molly Warsh of the University of Pittsburgh. Molly was identified as our top choice through an extensive nomination process that began in early 2020, when Simon first made known his intention to step down, and developed through consultations with the journal's various stakeholders, including the $J E M H$ editorial board, Brill publishing, and the University of Minnesota. All involved were overwhelmed by her combination of intellectual breadth and organizational experience, and were delighted when she accepted our offer to lead the journal. Many readers of $J E M H$ will already be familiar with Molly through her scholarship, particularly her fantastic recent monograph American Baroque: Pearls and the Nature of Empire, 1492-1700 (UNC Press, 2018), or through her continuing work as associate director of the University of Pittsburgh's highly regarded World History Center. She brings extraordinary new energy and a host of new ideas about future directions for JEMH, and it is with great excitement that we begin this new phase of the journal together.

Finally, we would be remiss if we did not also mention an important moment of transition for the Journal of Early Modern History's host institution. Since its founding in 1997, JEMH has enjoyed a special relationship with the University of Minnesota's Center for Early Modern History, whose founding director, James Tracy, was also a founding editor of the Journal. More recently, JE $M H$ has benefitted from a formal relationship with the center, emblazoned on our masthead since 2010, as $C E M H$ 's "official journal." Over the course of the last year, however, $C E M H$ has been planning a merger with a sister institute, the University of Minnesota's Center for Medieval Studies, and as of this month these two centers have now been officially recombined to form a new interdisciplinary center: the University of Minnesota's Center for Premodern Studies.

This change is not one that will visibly affect the Journal's operations in the short term, involving the formal merger of two centers whose activities were already extremely closely integrated (to the point of sharing the same offices and administrative staff for the past several years). Nevertheless, it does create a new structure designed to bring greater interdisciplinarity and wider chronological focus to both medieval and early modern studies. Since these are goals that are equally shared by the editorial team of $J E M H$, we eagerly look forward to a future with both a new editor and a new institutional home-even as we retain an unwavering commitment to maintaining the standards and the reputation of JEMH that have been carefully built over the last twenty-five years.

Giancarlo Casale

Katharine Gerbner

Executive Editors 